\title{
Economic models in Ancient Near East economies
}

Input definitions:

- Economy - the core is the allocation of goods and resources

- Model - theoretical and simplified concept of reality the aim of which is to illustrate mechanisms governing the reality

Two assumptions:

- we do not treat Near East economy as a whole

- problem with precise statistical data referring to the ancient times

Models:

- circulations: production, storage, distribution and consumption

- $\mathrm{G}=\mathrm{f}(\mathrm{P}, \mathrm{R}, \mathrm{T}, \mathrm{I})$, where $\mathrm{G}$ is global income (produced goods), $\mathrm{P}$ - people, $\mathrm{R}$ - resources, $\mathrm{T}$ - technology and I - institutions

- cooperation between state (including religious institutions) and private sector

- question of existence of market economy - demand and supply with price or its equivalent as a tool of relation

Terms and persons to clarify:

- $n m h$ (Egyptian) - people, who had own land and paid taxes to the royal treasure $=\dot{\varepsilon} \lambda \varepsilon v \dot{\theta} \theta \varepsilon \rho \varsigma($ Greek $)$

- tamkaru (Akkadian) - royal clerks who performed long-distance trade for fixed prices

- embeddedness - economic behaviour in certain historical and social conditions as well as cultural and even religious ones

- John Maynard Keynes - British economist (1883-1946) Keynesianism idea assumes a great role of the state as the creator of demand

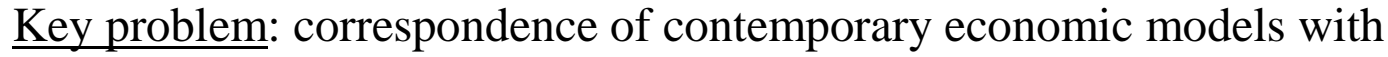
the reality of the ancient Near East

Question of the talk: translation of economic rules current in our times into different realities in the earlier times - continuity vs. change 